\title{
Can we still ignore renal replacement therapy in sub-Saharan Africa? All living beings are created equal
}

\author{
Shuzo Kobayashi and Sumi Hidaka
}

\begin{abstract}
This review addresses the social background and renal replacement therapy in the sub-Saharan African region. We also describe the hemodialysis treatment in countries that we have supported since 2008 and the renal transplant treatment in Tanzania that began in 2016. We have contributed dialysis treatment totally to 15 sub-Saharan African countries. Many patients suffering from chronic renal failure have been able to be treated by hemodialysis, and with this technique, lots of patients with acute kidney injury have also been rescued. In order to ensure the sustainability of dialysis treatment, clinical engineers in Japan should be needed because of the maintenance of dialysis machines and management of dialysate. Kidney transplantation would be the best method in renal replacement therapy. It would be also important to be able to perform transplant operation only by the local staff, to strengthen the examination system, and to foster transplant internists by further training. In this regard, our efforts surely made it possible that kidney transplant was conducted successfully in Tanzania.
\end{abstract}

Keywords: Sub-Saharan Africa, Hemodialysis, Kidney transplantation

\section{Introduction}

Nelson Mandela (1918 2013) says that no one is born hating another person because of the color of his skin, or his background, or his religion. People must learn to hate, and if they can learn to hate, they can be taught to love, for love comes more naturally to the human heart than its opposite [1].

We have supported treating patients with end-stage renal disease (ESRD) in sub-Saharan African countries for these 12 years based on our fundamental policy; "All living beings are created equal." We have believed that not devices but education can change the medicine in subSaharan African countries, which is quite similar to the quotes by Nelson Mandela; "Education is the most powerful weapon which you can use to change the world" [1].

In this review, we give an account of the economic state and renal replacement therapy (RRT) in sub-Saharan Africa at first, and then move to our contribution in hemodialysis (HD) treatment and kidney transplantation.

* Correspondence: shuzo@shonankamakura.or.jp

Kidney Disease and Transplant Center, Shonan Kamakura General Hospital, 1370-1 Okamoto, Kamakura 247-8533, Japan
Geography and demography of sub-Saharan Africa

Africa is the world's second largest and second populous continent, after Asia [2]. Although the economic growth in Africa has been remarkable in recent years, the gap between rich and poor people is severe and there are still many people who cannot live in good sanitation and cannot access medical resources. Approximately $80 \%$ of Africa's total area is occupied by so-called sub-Saharan Africa. This is a geographical term which describes African countries fully or partially located south of the Sahara Desert (Fig. 1) [3]. The sub-Saharan Africa region is also known as "Black Africa," in contrast to the "Caucasoid" inhabitants of North Africa.

According to the 2017 revision of the World Population Prospects, the population of sub-Saharan Africa was $995,694,907$ in 2016. Its current growth rate is $2.3 \%$. More than $40 \%$ of the population in sub-Saharan countries is younger than 15 years old [4].

\section{Economics and health indicators in sub-Saharan countries}

(i) Human Development Index (HDI)

(c) The Author(s). 2020 Open Access This article is distributed under the terms of the Creative Commons Attribution 4.0 International License (http://creativecommons.org/licenses/by/4.0/), which permits unrestricted use, distribution, and reproduction in any medium, provided you give appropriate credit to the original author(s) and the source, provide a link to the Creative Commons license, and indicate if changes were made. The Creative Commons Public Domain Dedication waiver (http://creativecommons.org/publicdomain/zero/1.0/) applies to the data made available in this article, unless otherwise stated. 


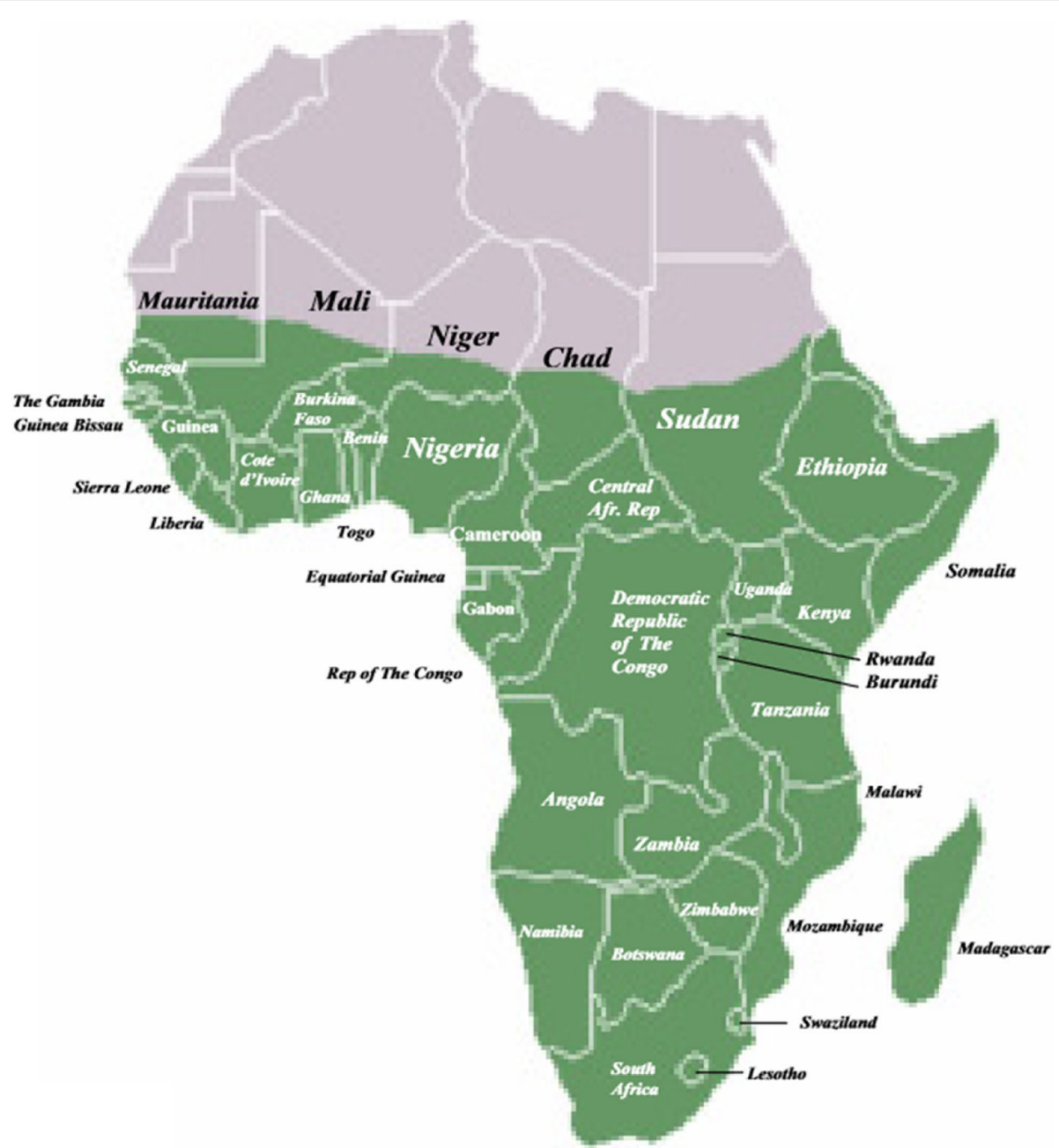

Fig. 1 Map of sub-Saharan Africa (ref. [3]): The green part of Africa corresponds to sub-Saharan Africa

The HDI is a statistic composite index of life expectancy, educational attainment, and gross national income (GNI) per capita. The HDI has captured human progress, combining information on people's health, education, and income in just one number [5]. According to the United Nations Development Program (UNDP) Report 2018, progress on the HDI since 1990 has not always been steady (Fig. 2). Some countries suffered reversals due to conflicts, epidemics, or economic crises. HDI reported in 2014 was $0.890,0.891,0.911$, and 0.944 in Japan, Korea, USA, and Norway, respectively.

The HDI value is still very low in sub-Saharan countries compared with that of Organization for Economic Co-operation and Development (OECD) countries. SubSaharan Africa had losses in the 1990s, when conflict and the HIV/AIDS epidemic caused life expectancy to drop dramatically. However, Sub-Saharan Africa went from the second slower growing region on the HDI in the 1990s to the fastest growing region between 2000 and 2010. (ii) Health indicators (The World Bank Data)

Life expectancy at birth in sub-Saharan Africa was 50.5 years old in 2000 , but the value improved to 60.8 in 2017 [6]. The world average of this value was 67.7 years old in 2000 and 72.7 in 2017. Under 5 years old, mortality rate of the world was 77.1 per 1000 live birth in 2000 and 39.1 in 2017. On the other hand, under 5 years old mortality rate was 153.7 per 1000 live birth and improved to 75.5 in 2017, but the mortality rate is still high in sub-Saharan Africa. Prevalence of HIV among people aged $15-49$ years was $5.6 \%$ in 2000 and $4.1 \%$ in 2017 in sub-Saharan Africa. The world average of this value was $0.8 \%$ in 2000 and still $0.8 \%$ in 2017.

(iii) Health financing

Concerning total health expenditure on health per capita per year, US\$ $30-40$ is estimated to be the minimum expenditure on health required for essential health 


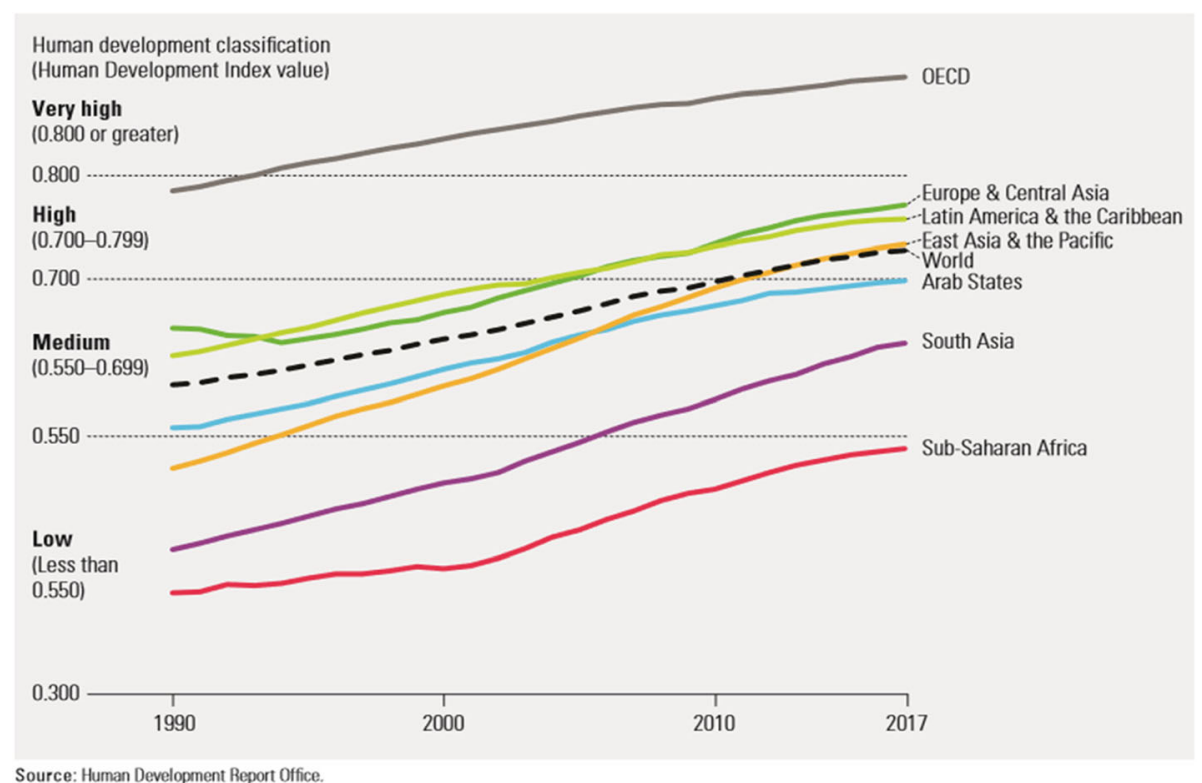

Fig. 2 Human Development Index values, by country grouping, 1990-2017 (ref. [5]): OECD, Organization for Economic Co-operation and Development

interventions [2]. The average value in OECD countries was US\$ 4555.74 in 2013 [4]. Figure 3 shows total expenditure on health per capita at exchange rate in African countries in year 2013 and 1995 [4]. It increased in 2013 compared with that of 1995 in all African countries, but still these values were very low in many countries. The average in African countries was only US\$ 222 in 2013, and approximately $40 \%$ of African countries spent for health less than US\$ 100.

The total spending on health per person for 2011 is positively correlated to the wealth of each country (Fig. 4) [4]. The higher the country's gross domestic product (GDP), the higher the health expenditure. It has also become apparent the correlation is more significant in the countries with GDP per capita less than US\$30,000. For reference, GDP per capita of Japan in 2011 shown in black circle in Fig. 4 is US\$ 48,169 and total health expenditure per capita is US\$ 4207.

\section{Renal replacement therapy in the world}

It is very difficult to obtain accurate and reliable data about RRT in the world. According to the report from Fresenius Medical care, the number of patients being treated for ESRD globally was estimated to be 2,786,000 at the end of 2011 [7]. Of these patients, approximately $1,929,000$ were undergoing $\mathrm{HD}, 235,000$ were undergoing peritoneal dialysis (PD), and 622,000 people were living with kidney transplants. Annual growth rate of ESRD patients was $6-7 \%$, which continues to increase at a significantly higher rate than that of the world

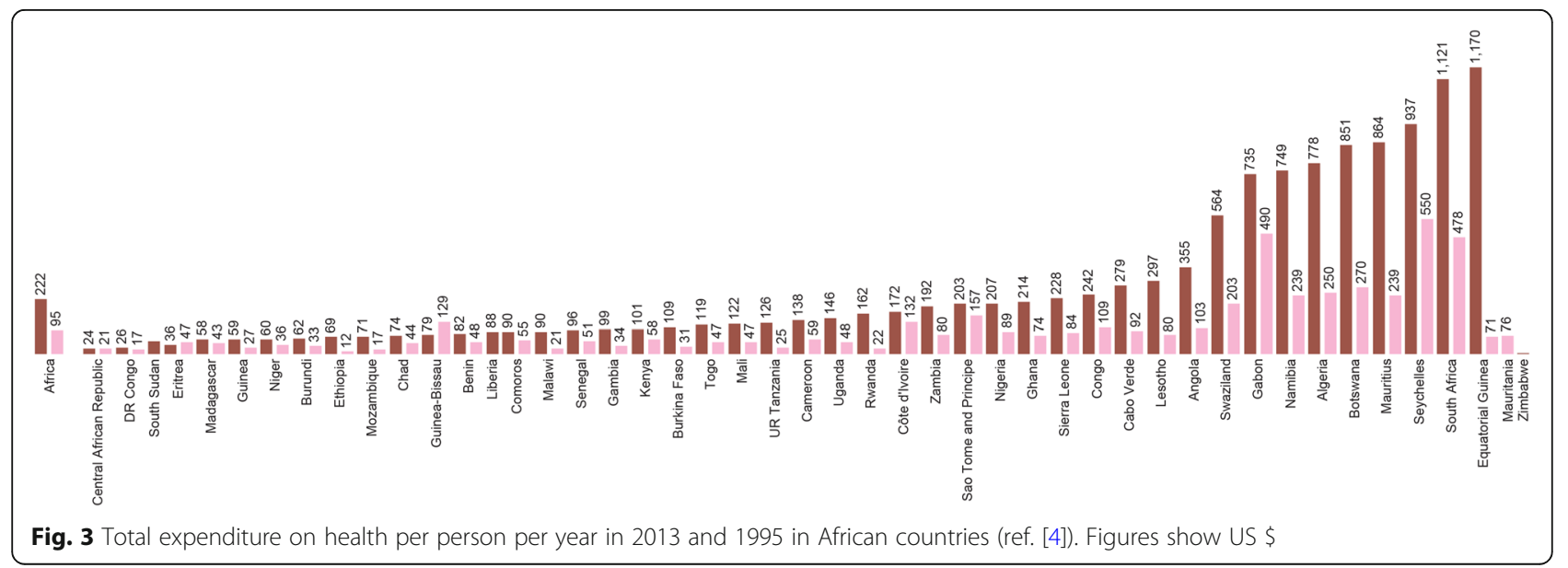




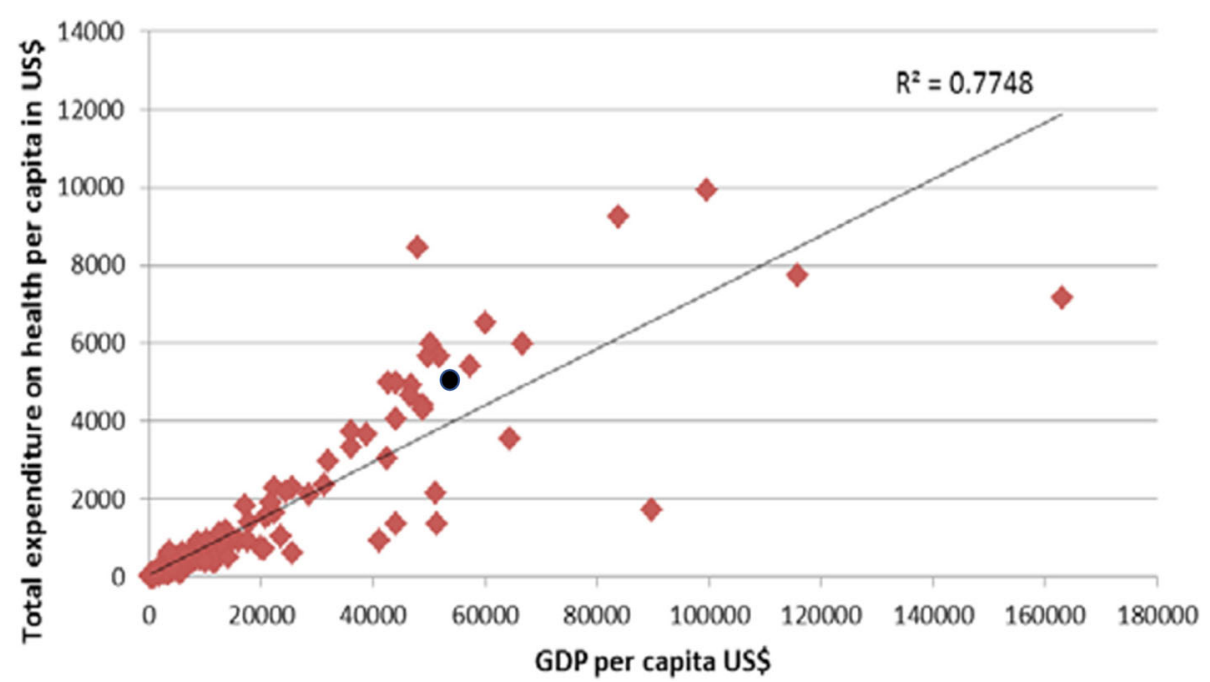

Fig. 4 The relationship between wealth and health expenditure in 2011 (ref. [4]): Wealth and health expenditure are correlated. Black circle demonstrates Japanese data

population (1.1\%). The population of ESRD patients has increased steadily, and more than three-quarters of all ESRD patients were consistently treated by HD or PD.

Figure 5a shows the relation between GDP per capita and the prevalence of ESRD patients in 2011 [7]. The prevalence of treated ESRD patients demonstrates a high variation, ranging from under 100 to approximately 3000 patients per million population (pmp). ESRD prevalence is highest in Taiwan with around $2850 \mathrm{pmp}$, followed by Japan with around $2490 \mathrm{pmp}$, and then the USA with around 1970 pmp. The average of European Union (EU) countries was 1040 pmp. The global average was around $400 \mathrm{pmp}$, although dialysis prevalence was around $310 \mathrm{pmp}$, which suggests that accesses to RRT is limited in many countries and a number of ESRD patients cannot receive RRT.
GDP expresses national economic strength. There is no significant correlation between GDP per capita and ESRD prevalence in countries with a GDP per capita more than US\$10,000. However, GDP and prevalence of ESRD was significantly correlated among the countries with a GDP less than US\$10,000. Ab-Aisha and Elamin demonstrated the relation between GDP per capita and prevalent dialysis population in African countries (Fig. 5b) [2]. While the survey periods differ between Fig. 5a and Fig. 5b, the prevalence of dialysis in relatively wealthy African countries (Botswana, South Africa, Namibia, and Swaziland) is much lower than expected from the GDP. These countries belong to Southern Africa, a subregion where adult prevalence of HIV/ AIDS is very high ranging from 12.1 to $27.4 \%$ in 2017
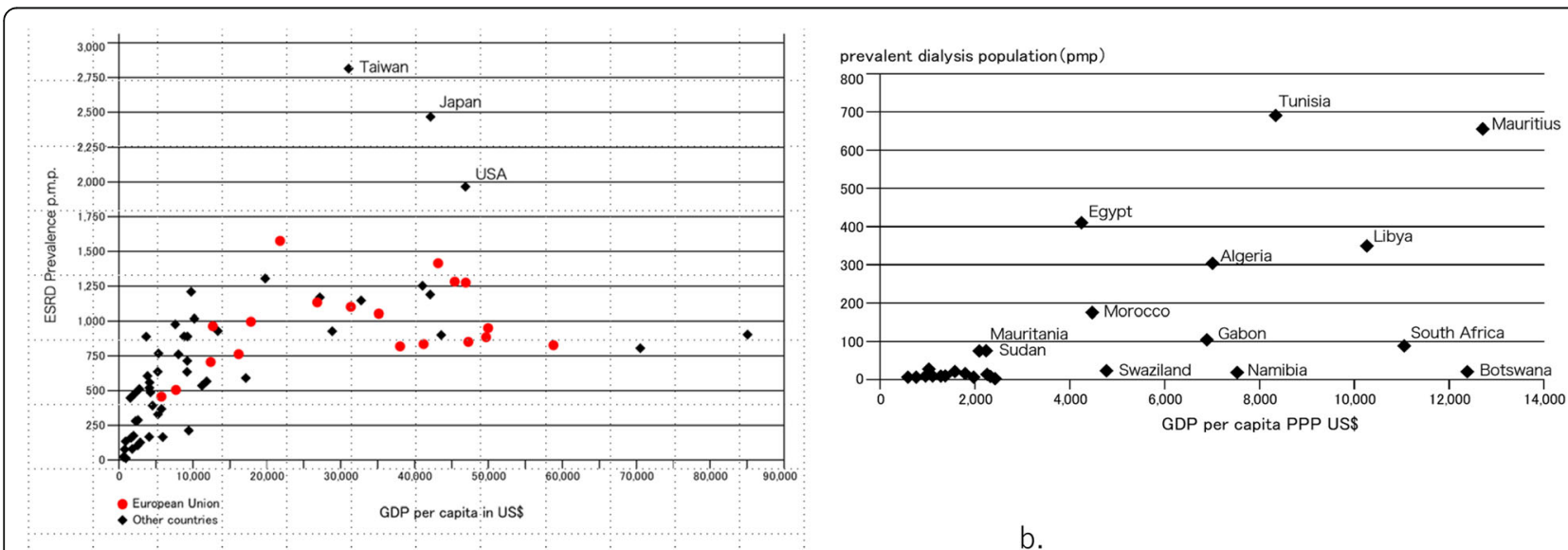

Fig. 5 a The relation between GDP per capita in US\$ and prevalence of ESRD patients in 2011 (ref. [7]): Red circles mean each EU countries, and black rhombi mean other countries. b GDP per capita (2005) versus prevalence of dialysis patients in different African countries (2007) (ref. [2]) 
[8]. Therefore, there seems to be an impact that can be prioritized as a system for maintaining national health.

\section{Renal replacement therapy in African countries}

(i) The first steps of dialysis treatment in Africa

Dialysis treatment is a highly sophisticated and expensive medicine; therefore, sociopolitical and economic stability is required to perform dialysis treatment.

The beginning of dialysis activity in Africa was in 1957 in South Africa, when only it was just 12 years after the first dialysis treatment by Willem Kolff [9]. The next dialysis treatment was performed in Egypt, but the patient died after a few sessions. In early 1960s, HD and PD were used routinely for the management of acute renal failure (ARF) in Cairo and Johannesburg university hospitals. Dialysis treatment also started in Tunisia, Algeria, and Kenya during the same period. The first patient who received HD by a Scribner shunt in Africa was treated at Cairo in 1964. After that, dialysis treatment was gradually expanded in Nigeria (1965), Sudan (1968), Libya (1972), Zimbabwe (1972), and Morocco (1977). Dialysis for treatment of ARF patients was adopted in other leading teaching institutions in the rest of Africa.

\section{(ii) Maintenance dialysis in Africa}

The timeline of initiating maintenance dialysis services in different African countries is widely variable. Almost all maintenance dialysis programs in Africa started only after achievement of independence, peace, and political stability [9]. Africa was a target for imperialism of European countries. Ninety percent of African continent was occupied by 1914. The exception were Liberia and South Africa. Liberia has never been occupied, and South Africa became independent in 1910. Before 1950, only two countries gained independence; Egypt in 1922 and Ethiopia in 1941. Whole African countries finally gained independence in 1993. Notably, no African countries started a maintenance dialysis program before independence of the country (Fig. 6).

El Matri et al. demonstrated that maintenance dialysis treatment was available in 32 African countries in 2007 [10]. The total number of patients on HD is just over 60,000 patients ( $<50$ pmp in many countries). PD is only available in 12 African countries, and the total number of PD patients is around 2000.

Table 1 shows the number of prevalent HD and PD patients in different African countries in 2007 reported by Abu-Aisha et al. [2]. Patients undergoing HD was 67,000 and 2050 undergoing PD in African countries in 2007. The availability of RRT is variable in Africa, but generally is better in North Africa, where figures of RRT ranging between 30 and $186.5 \mathrm{pmp}$ have been recorded [3].
Compared with that in North African countries, the frequency of RRT is very low in the sub-Saharan African countries.

We also must know so many people cannot access HD or PD in many sub-Saharan African countries even in 2010 from Fig. 6.

\section{Kidney transplantation in sub-Saharan Africa}

El Matri et al. demonstrated in 2008 that renal transplantation is performed in 10 of the 53 countries, and only 5 countries (Egypt, South Africa, Tunisia, Algeria, and Sudan) have sustained programs that perform more than 50 cases per year [10]. In 2012, Pozo et al. demonstrated that in the 47 sub-Saharan African countries, Kenya, Nigeria, and South Africa were the only countries with renal transplantation programs and reported rates per million population of 0.60 , 0.23 , and 5.12 , respectively [11], Table 2 .

Recently, Moosa demonstrated the state of kidney transplantation in South Africa between 1991 and 2015 (Fig. 7) [12]. In South Africa, 7191 kidney transplants were performed. The overall kidney transplant rate was $6.4 \mathrm{pmp}$, averaging $4.8 \mathrm{pmp}$ in the public sector and $15.2 \mathrm{pmp}$ in the private sector; $58.3 \%$ of the donor kidneys were derived from deceased donors. Cape Town and Johannesburg hospitals performed $75 \%$ of the country's kidney transplants. The overall transplant rate in South Africa is declining, especially in the public sector. A shortage of donor is also a problem in South Africa.

\section{Activities of our medical group}

We have continued to provide the chances to treat the patients with ESRD by donating 161 dialysis machines including reverse osmosis and demineralization water clean systems to 15 sub-Saharan African countries since 2008 (Table 3), based on the policy of our medical group; "All living beings are created equal"

It is not only donating machines but also educating medical staffs. Our policies for supporting dialysis therapy in sub-Saharan countries based on the two basic concepts; the first is to teach how to fish, not to give fish, and the second one is not to take away even one coin but, if any profit, it should be used for medicine in each country.

\section{Supports for sub-Saharan countries on HD treatment}

\section{(i) Republic of Mozambique}

It was 2008 when we first established HD therapy in Maputo, a capital city in Mozambique (Fig. 8a, b). Basically, except a couple of patients with AKI, they had never done dialysis therapy for the patients with chronic renal failure (CRF). At least, they did not have any facilities to treat maintenance HD patients. After investigating water 


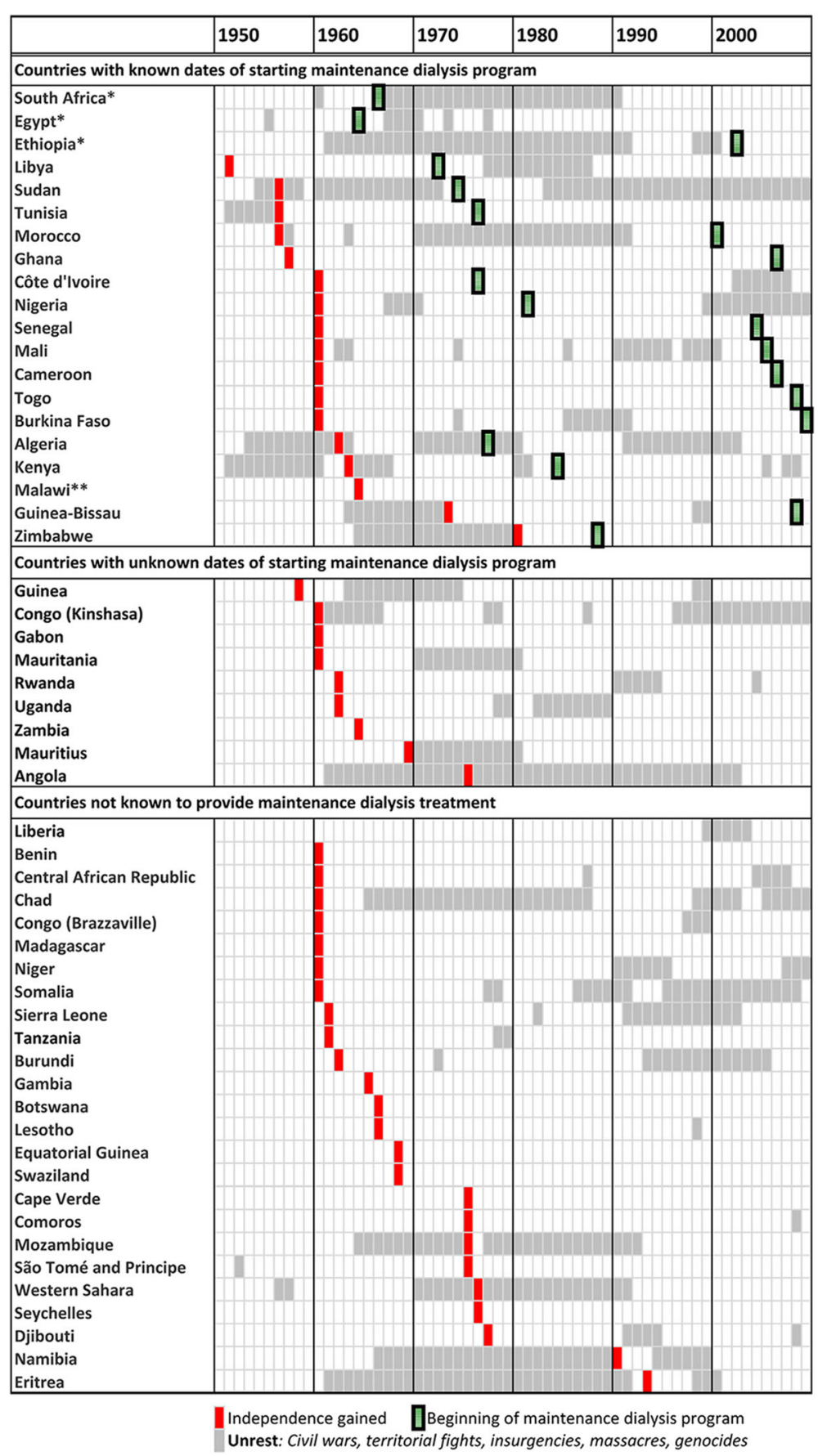

Fig. 6 The effect of wars and other forms of violence on the development of maintenance dialysis programs in Africa. (ref. [9]): The red rectangles mean the year of independence gained. The green rectangles mean the year of starting maintenance dialysis program. The gray rectangles mean the year of various unrest happened, i.e., civil wars, territorial fights, insurgencies, massacres, and genocides. * Means the countries

quality and electricity, Nipro Co., Ltd. (Osaka, Japan) cooperated well with our group to install machines.

One doctor, two nurses, and one medical engineer came to Japan from Mozambique to learn the basic techniques for 4 weeks (Table 4), then alternatively, our medical team including two doctors, a nurse, and a clinical engineer visited their country and stayed for 4 weeks to teach and confirm if everything that we had already instructed was going well (Table 3).

Electric power supply was not stable, although water purity was good enough in Mozambique (Table 5), so that dialysis solution (dialysate) could not be pumped 
Table 1 Number of prevalent HD and PD patients in different African countries (2007)

\begin{tabular}{|c|c|c|c|c|}
\hline Country & $\begin{array}{l}\text { Dialysis } \\
\text { patients }\end{array}$ & $\begin{array}{l}\mathrm{HD} \\
\text { patients }\end{array}$ & $\begin{array}{l}\text { PD } \\
\text { patients }\end{array}$ & $\begin{array}{l}\text { Dialysis patients on } \\
\text { PD (\%) }\end{array}$ \\
\hline Egypt & 33110 & 33000 & $<20$ & 0 \\
\hline Algeria & 10160 & 9900 & 260 & 3 \\
\hline Tunisia & 7160 & 6880 & 280 & 4 \\
\hline Morocco & 5680 & 5660 & $20-50$ & 0 \\
\hline South Africa & 3660 & 2450 & 1170 & 32 \\
\hline Sudan & 2850 & 2750 & 100 & 3 \\
\hline Libya & 2150 & 2100 & $51-100$ & 2 \\
\hline Nigeria & 1130 & 1130 & - & 0 \\
\hline Mauritius & 820 & 820 & - & 0 \\
\hline Cote d'Ivoire & 460 & 460 & - & 0 \\
\hline Ethiopia & 460 & 460 & - & 0 \\
\hline Kenya & 380 & 340 & $20-50$ & 12 \\
\hline Angola & 290 & 290 & - & 0 \\
\hline Benin & 250 & 250 & - & 0 \\
\hline Mauritania & 240 & 240 & - & 0 \\
\hline Cameroon & 220 & 220 & - & 0 \\
\hline Gabon & 150 & 150 & - & 0 \\
\hline Senegal & 130 & 110 & $20-50$ & 18 \\
\hline Ghana & $51-100$ & $51-100$ & - & 0 \\
\hline Madagascar & $51-100$ & $51-100$ & - & 0 \\
\hline Botswana & $20-50$ & - & $20-50$ & 100 \\
\hline DR Congo & $20-50$ & $<20$ & $<20$ & 25 \\
\hline Mali & $20-50$ & $20-50$ & - & 0 \\
\hline Namibia & $20-50$ & $20-50$ & $<20$ & 43 \\
\hline Togo & $20-50$ & $20-50$ & - & 0 \\
\hline Uganda & $20-50$ & $20-50$ & $<20$ & 14 \\
\hline Zambia & $20-50$ & $<20$ & $<20$ & 50 \\
\hline Zimbabwe & $20-50$ & $20-50$ & $20-50$ & 44 \\
\hline Mozambique & $<20$ & $<20$ & $<20$ & 25 \\
\hline Swaziland & $<20$ & $<20$ & - & 0 \\
\hline Tanzania & $<20$ & $<20$ & - & 0 \\
\hline Total & 69800 & 67700 & 2050 & 3 \\
\hline
\end{tabular}

$H D$ hemodialysis, $P D$ peritoneal dialysis [2]

up, leading to ring alarm often from dialysis machine that we had never experienced in Japan.

Only it was almost 12 years ago when the Minister of Health proudly announced that they were able to treat the patients successfully with uremia like westernized countries through TV to all people in Mozambique. Clearly, increasing access to global media means that patients are becoming aware of the life-saving potential of dialysis.

We visited again 5 years after our first visit and felt much satisfied to see everything was doing well. The number of maintenance HD patients increased up to 54 patients using
Table 2 Total transplants and type for Kenya, Nigeria and South Africa for 2005-2008

\begin{tabular}{|c|c|c|c|c|}
\hline Country & 2005 & 2006 & 2007 & 2008 \\
\hline \multicolumn{5}{|l|}{ Kenya } \\
\hline LRTX & & 22 & 26 & 23 \\
\hline Rate PMP & & 0.63 & 0.72 & 0.60 \\
\hline \multicolumn{5}{|l|}{ Nigeria } \\
\hline LRTX & 60 & 20 & 14 & 35 \\
\hline Rate PMP & 0.48 & 0.15 & 0.10 & 0.23 \\
\hline \multicolumn{5}{|l|}{ South Africa } \\
\hline RTX & 232 & 223 & 209 & 250 \\
\hline PMP RTX & 4.95 & 4.68 & 4.38 & 5.12 \\
\hline LRTX & 84 & 91 & 85 & 90 \\
\hline PMP LRTX & 1.79 & 1.91 & 1.78 & 1.84 \\
\hline DRTX & 148 & 132 & 124 & 160 \\
\hline PMP DRTX & 3.16 & 2.77 & 2.60 & 3.28 \\
\hline
\end{tabular}

PMP per million population, $R T x$ renal transplantation, $L R T x$ living donor renal transplantation, DRTX deceased donor renal transplantation [11]

10 dialysis machines. During this period to ensure sustainability, doctors, nurses, and medical engineers have kept in touch regarding various problems each other.

We must consider in terms of economy. It costs US\$ 1 to get 1 vial of penicillin, and US\$ 4 is given to one patient annually in 2008. Although economy is rapidly improving in Mozambique, dialysis treatment costs US\$ 100 200 per session, it is equivalent to $20 \sim 40 \%$ of the GDP per capita. For only government officers or certain company persons, this medical care is provided free. Still, all living beings are not created equally. They must buy a dialysis circuit with drug every session for dialysis of the day, paying money every time; otherwise, they cannot receive dialysis treatment on the day.

(ii) Supports on HD center after Mozambique

After successful establishment HD center in Mozambique, we have continuously supported dialysis treatments in subSaharan African countries shown in Table 3.

In Mozambique, we often experienced electric power problems so that HD treatment was forced to stop for several minutes. In Djibouti, the main problem was very high concentrations of sodium in tap water compared to the Guidelines for drinking-water quality (GDWQ) (Table 5) [13]. No municipal water can be considered safe for use in HD applications in the absence of a treatment system. All dialysis facilities therefore require an appropriately designed and correctly maintained water treatment system to safeguard patients. We had to use reverse osmosis systems in series, normally used in parallel.

In Tanzania, Swaziland, and Malawi, the tap water contained a lot of fine soil-like things; therefore, another 


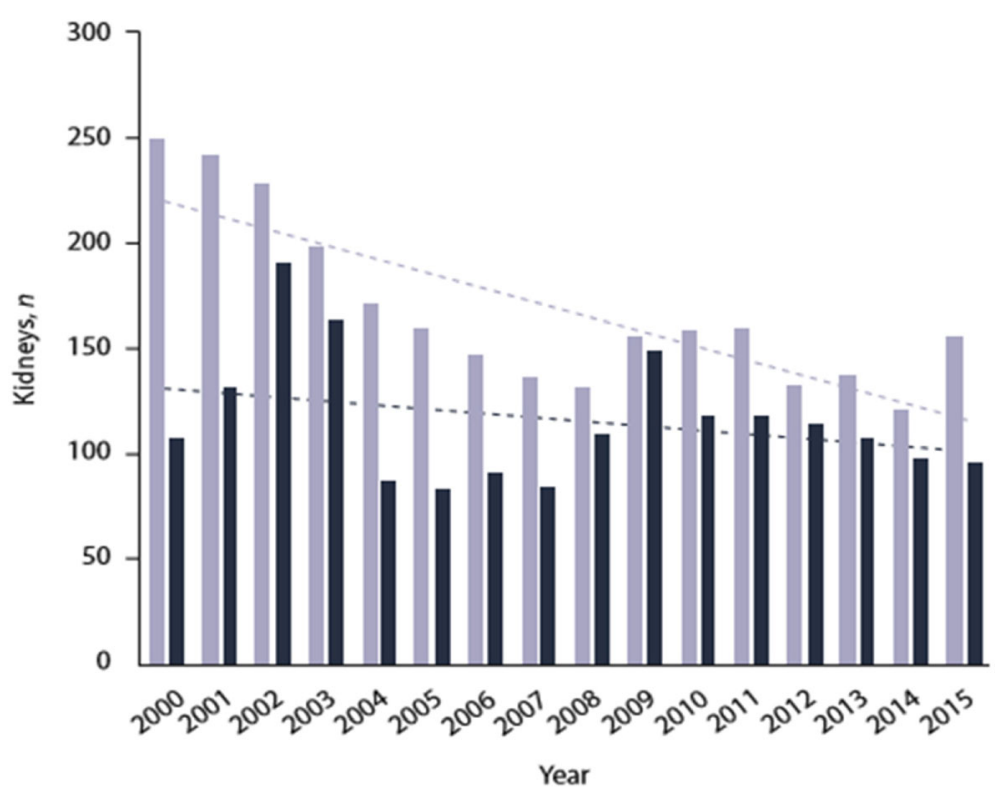

Deceased donor $(n=2690)$

Living donor ( $n=1855)$

Linear (deceased donor $(n=2690)$ )

..... Linear (living donor $(n=1855)$ )

Fig. 7 Number of kidneys transplanted from deceased and living donors in South Africa, 2000-2015. Trends lines are shown (ref. [12])

Table 3 Sub-Saharan African countries supported by Tokushukai Medical Group installation machines and on-site instruction from Japan

\begin{tabular}{|c|c|c|c|c|}
\hline & Country & $\begin{array}{l}\text { Year of } \\
\text { installation }\end{array}$ & $\begin{array}{l}\text { Number of dialysis } \\
\text { machines }\end{array}$ & $\begin{array}{l}\text { On-site } \\
\text { instruction }\end{array}$ \\
\hline 1 & Mozambique & July 08 & 10 & December 08 \\
\hline 2 & Djibouti & March 10 & 15 & April 10 \\
\hline 3 & Zambia & October 10 & 10 & November 10 \\
\hline 4 & Rwanda & February 11 & 15 & \\
\hline 5 & Guinea & October 11 & 10 & \\
\hline 6 & Swaziland & November 11 & 10 & April 13 \\
\hline 7 & Uganda & December 11 & 10 & \\
\hline 8 & Cameroon & February 12 & 10 & June 12 \\
\hline 9 & Tanzania & June 12 & 10 & January 13 \\
\hline 10 & Mauritania & October 12 & 10 & \\
\hline 11 & Ghana & December 12 & 10 & August 13 \\
\hline 12 & Malawi & July 13 & 10 & November 13 \\
\hline 13 & Togo & February 14 & 11 & March 14 \\
\hline 14 & Lesotho & July 17 & 10 & \\
\hline \multirow[t]{2}{*}{15} & DR Congo & Apr 18 & 10 & \\
\hline & Total & & 161 & \\
\hline
\end{tabular}

prefilter was required to remove them, and we had to exchange the prefilter every couple of days (Fig. 9). The role of medical engineers in this field is extremely important.

\section{Summary on HD support}

We accepted 23 medical teams from 19 sub-Saharan African countries for education and instruction of RRT (Table 4). It means they learned mainly HD, but they could know PD and kidney transplantation in Japan. They also learned at the laboratory of Nipro Co. Ltd. to watch the inside of the dialysis machine and the precise mechanisms of it.

Furthermore, we have contributed dialysis treatment totally to 15 sub-Saharan African countries (Table 3), and on-site training by the Japanese team was performed in 9 of 15 countries. It costs around US\$ 8.4 million. Total number of donated machines is 161 for subSaharan African countries.

No one should be dying of untreated acute kidney injury (AKI) by 2025 as reported in 2015 World Congress of Nephrology in Cape Town [14]. Indeed, when our Japanese team just landed at the airport in Tanzania, the doctors, who had heard the information regarding the patient with AKI suffered from disseminated intravascular coagulation (DIC) after baby delivery, instantly could help the 


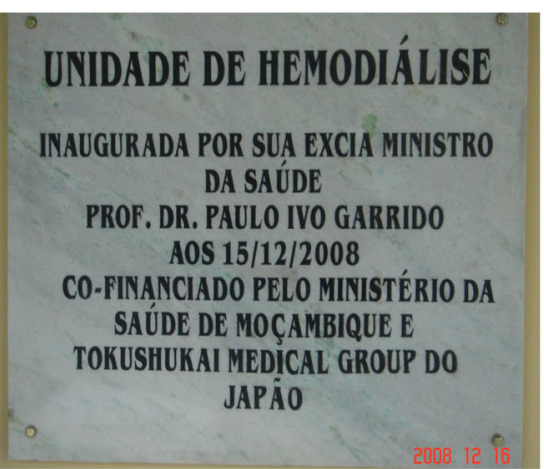

a.

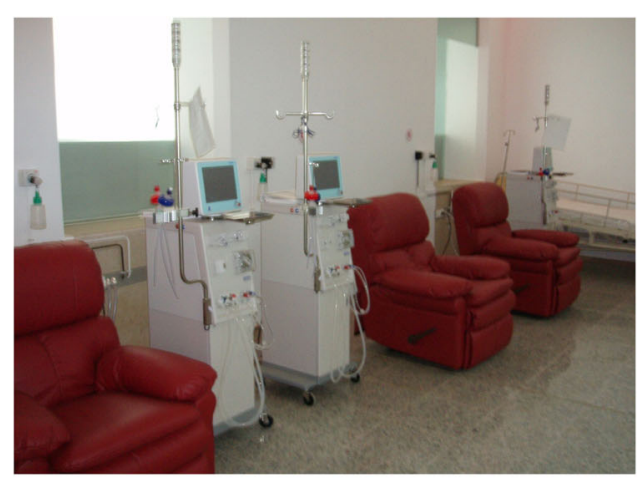

b.

Fig. 8 Dialysis center in Mozambique: a A memorial plate decorated on the wall of dialysis center. b Inside view of dialysis center. Ten dialysis machines were settled

patient with dialysis therapy in hospital. A foreign sightseeing visitor who suffered from AKI due to Malaria infection was also helped with dialysis therapy, and it is reported as a case report [15]. It goes without saying that such patient as described above are treated with dialysis therapy. But we should know the fact that there are still

Table 4 Medical groups who trained dialysis therapy in Japan

\begin{tabular}{llll}
\hline & Country & Year of training in Japan & Experience of hemodialysis \\
\hline 1 & Mozambique & August 08 & no \\
2 & Mozambique & August 09 & a little \\
3 & Djibouti & February 10 & no \\
4 & Eritrea & July 10 & no \\
5 & Swaziland & July 10 & no \\
6 & Rwanda & July 10 & a little \\
7 & Zambia & August 10 & a little \\
8 & Cameroon & September 10 & well \\
9 & Tanzania & November 10 & no \\
10 & Guinea & August 11 & well \\
11 & Uganda & September 11 & a little \\
12 & Cote d'lvoire & September 11 & no \\
13 & Rwanda & September 11 & a little \\
14 & Malawi & December 11 & a little \\
15 & Mauritania & December 11 & well \\
16 & Lesotho & February 12 & a little \\
17 & Togo & February 12 & well \\
18 & Ghana & June 12 & a little \\
19 & Ghana & June 13 & a little \\
20 & Liberia & June 13 & no \\
21 & Tanzania & August 13 & a little \\
23 & BR Congo & July 15 & well \\
\hline
\end{tabular}

such patients who are not able to get the chances even any treatment in sub-Saharan African countries.

Now, also we need to bring an action for CKD. It is very important to prolong the life of the patient with CKD due to non-communicable diseases like diabetes mellitus, obesity, or hypertension.

In order to extend dialysis program in Africa, the system in clinical engineers such as Japan should be organized. In 1988, the Japanese government admitted clinical engineering as a national license. To ensure sustainability of dialysis treatment, maintenance of machine is mandatory so that Japanese clinical engineers could actively work in these countries. No other countries like Japan admit clinical engineering as a national license. They rely on manufacture-based medical engineers. They do not see the patients in facilities everyday like Japan nor touch patients at all.

Meremo et al. published the challenges and outcomes of HD center in Dodoma, Tanzania, where we supported to establish HD center at 2013 [16]. They have had no experiences to treat $\mathrm{HD}$ at the beginning of 2013, but they treated 116 patients with HD from January 2013 to June 2015. Each dialysis session was charged at a cost of US\$ 150 for patients on National Health Insurance Fund (NHIF) scheme and US\$ 175 for those paying out of pocket. Of the 116 patients, 32 (27.6\%) had AKI, of them $26(81.3 \%)$ patients had recovery of renal function after HD. Eighty-four $(72.4 \%)$ patients had ESRD. The odds ratio for poor outcomes was 7.3 times for a patient with ESRD (95\% CI 3.26-18.17, $p<0.001$ ). Patients who had no NHIF coverage also had higher odds of poor outcomes after starting HD (OR 6.6, 95\% CI 5.4-12.7, $p<0.001$ ).

Furthermore, support for HD has also been provided for each other sub-Saharan countries that we have supported. In DR Congo, dialysis machines were installed in 2018 and Japanese staff planned to visit and to start dialysis treatment. However, there was a problem with the 
Table 5 Examination of tap water in several sub-Saharan African countries

\begin{tabular}{|c|c|c|c|c|c|c|}
\hline Items & GDWQ & Mozambique & Djibouti & Swaziland & Ghana & Malawi \\
\hline Colour & $\overline{-}-15 \mathrm{TCU}$ & & & 5.0 & & \\
\hline Turbidity & $<1$ NTU & 0.5 & & 0.7 & 1.5 & 0.8 \\
\hline $\mathrm{pH}$ & $6.5 \sim 8.6$ & 7.8 & 8.0 & 7.4 & 6.9 & 7.6 \\
\hline Iron (mg/L) & $\overline{-}$ Mean 0.3 & & & & 0.28 & 0.018 \\
\hline Manganese (mg/L) & $<0.4$ & 32.4 & & & 0.074 & ND \\
\hline Nitrate (mg/L) & $<50$ & 1.4 & 0.0 & & 0.4 & 0.031 \\
\hline Ammonium (mg/L) & $\overline{1.5}$ & $<0.04$ & & & & \\
\hline Total dissolved solids (mg/L) & Median: 1000 & & & 15.7 & & \\
\hline Hardness (mg/L) & - & & & 9.2 & 70.0 & 64.0 \\
\hline Sodium (mg/L) & Median: 200 & & 592.0 & & & 11.0 \\
\hline Fluoride (mg/L) & 1.5 & & & & 0.4 & 0.5 \\
\hline E Coli (mg/L) & 0 & $<1$ & & & & \\
\hline
\end{tabular}

GDWQ "WHO guidelines for Drinking-water Quality", TCU true colour unit, NTU Nephlometric turbidity unit, E Coli Escherichia coli, — WHO guideline was not set

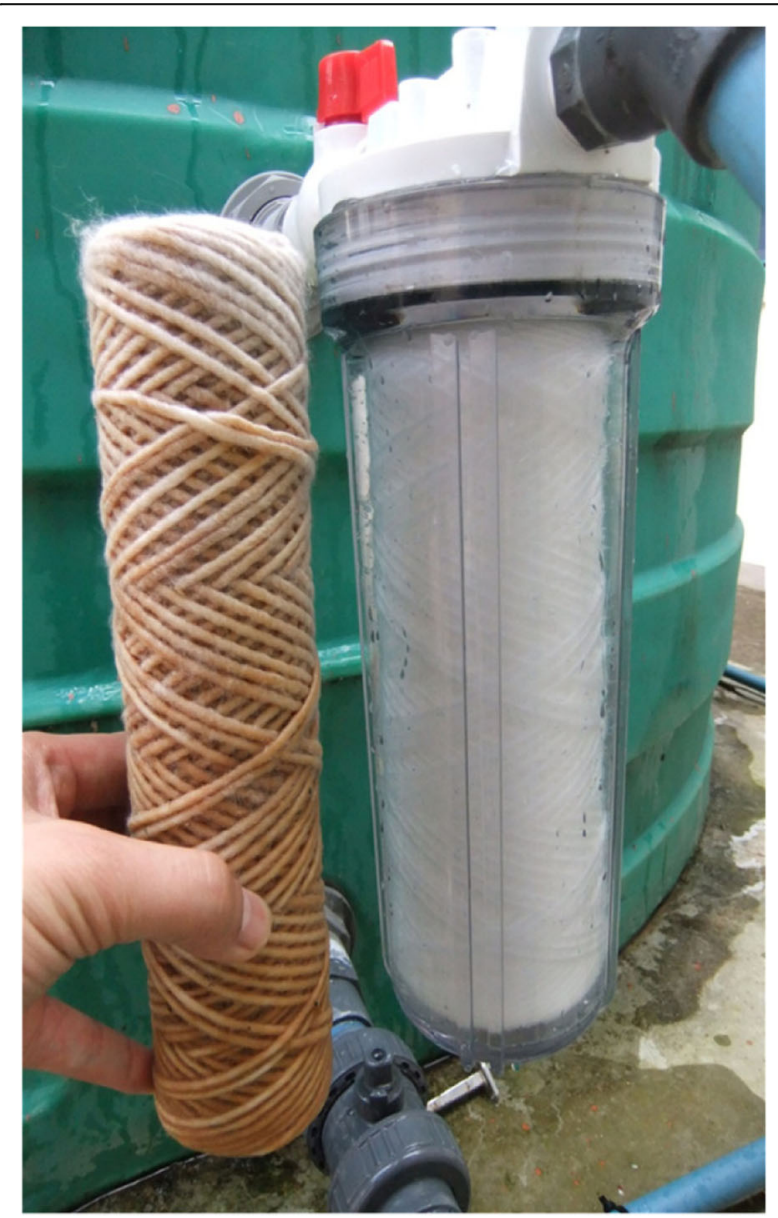

Fig. 9 Prefilter just after tap water tank in Swaziland. Prefilter just after the tap water tank that turns brown in a few days in Swaziland spread of Ebola hemorrhagic fever, then dialysis support was delayed. One nephrologist we had assisted in Cameroon in 2012 visited DR Congo in April 2019 and supported to start a HD center. It is great that African doctors help each other to treat the patients with ESRD.

\section{Kidney transplantation in Tanzania}

(i) The process to kidney transplantation execution at Dodoma, Tanzania

Following this contribution regarding HD, we then began to conduct the project for kidney transplant in Tanzania. It was 2016 when the 6th Tokyo International Conference on African Development (TICAD) was held in Nairobi, Kenya. Professor Kikula, the former vice chancellor of University of Dodoma (UDOM), requested help from our medical group on kidney transplantation. Dodoma is a new capital city in Tanzania. This request was based on memorandum of understanding (MOU) in 2003 between the former Tanzanian President, Mr. Benjamin Mukapa, and the former president of Tokushukai Medical Group, Dr. Torao Tokuda. It was going to provide modern specialties in diagnostic and curative services including laparoscopic surgeries and kidney transplant. However, almost nothing was established for kidney transplantation in 2016, when Benjamin Mukapa Hospital (BMH) was open in October 2016. This hospital is also a teaching hospital where it includes medical teaching and clinical internship for doctors and nurses. 
After returning to Japan, we asked Professor Kazunari Tanabe, at Tokyo Women's Medical University (TWMU) and consulted if we could collaborate together or not. In January 2017, the present president of Tokushukai, Dr. Takao Suzuki, with us visited Tanzania Embassy in Japan and confirmed our mutual understanding.

It is not our intention that we merely have kidney transplant operation, but to instruct how to prepare and operate followed by postoperation care in ICU. From the beginning, we had to instruct what kind of medical equipment such as those used in an operation theater for kidney transplantation, but also immune suppressants should be prepared, thus leading to establish their own system of kidney transplant medicine in Tanzania by their doctors and co-workers working in their country. Our project is totally different from the support that expert transplant surgeon visits to operate kidney transplantation upon paying, staying in short days in respective countries where they are required.

Meremo et al. demonstrated that renal transplantation is not performed in Tanzania and only a few patients can afford going abroad [16], especially to India until 2017. Kidney transplant recipient, donor, and a person who takes care of them go to India and stay there for a few weeks for the kidney transplant operation, after that they come back to Tanzania and get immunosuppressants from the hospital in Tanzania. The kidney transplant surgery costs US\$10,000 in Tanzania, but in cases that patients go to India for kidney transplantation as they have done so far, it costs US\$ 60,000 . In comparison to HD, kidney transplant costs half of them.

First of all, we requested to make legislations in Tanzania to avoid organ buying according to Istanbul Declarations [17].
Now a difficult but significant big project began since autumn in 2016 because at the moment, an operation theater even neither had been used nor constructed. On the contrary, MRI, CT, or other modern but well-used equipment like flow cytometer had been installed. Not all medical staffs in BMH do not get accustomed in using them.

Within 1 year, two teams separately including surgeons, urologists, physicians, and nurses came to be trained in both our hospital and TWMU. We, the Japanese team including surgeons, physicians, nurses, and laboratory technicians also went to see how everything was going well in BMH. The director in TWMU was concerned about the safety in Tanzania. It goes without saying that this project had been understood through the Japan International Cooperation Agency (JICA) and Ministry of Foreign Affairs (MOFA).

Unfortunately, everything was not going well due to the problem with supply system in BMH and UDOM. Many kinds of immunosuppressants and operation equipment like retractor which is used in case of retroperitoneum operation were not available, so we need to send it. It took a lot of time to have procedures between countries, through MOFA. Tokushukai Medical Group staffs, not only medical staffs but also officers working in headquarters, contributed much to complete the project. Moreover, we instructed the laboratory doctor and the technicians to use flow cytometer in measuring various kinds of immunological data. Finally, after overcoming many kinds of difficulties, we completed the project on 22 March 2018. We never forget the date when we together had a successful kidney transplant. This became the first case of kidney transplantation, of Tanzanian staffs, by Tanzanian staffs, and for Tanzanian patients. The patient was treated with HD for 1 year and got the donation from his sister.

Table 6 Summary of 7 kidney transplantation cases

\begin{tabular}{|c|c|c|c|c|c|c|c|c|c|c|c|c|c|c|c|}
\hline \multicolumn{7}{|c|}{ Recipient } & \multicolumn{2}{|l|}{$\underline{C D C}$} & \multicolumn{2}{|c|}{ FlowPRA } & \multirow[b]{2}{*}{$\begin{array}{l}\text { Latest } \mathrm{Cr}(\mu \mathrm{mol} / \\
\mathrm{L})\end{array}$} & \multicolumn{4}{|c|}{ Donor } \\
\hline & $\begin{array}{l}\text { Date of } \\
\text { KT }\end{array}$ & Age & Sex & $\begin{array}{l}\text { Blood } \\
\text { type }\end{array}$ & $\begin{array}{l}\text { Cause of } \\
\text { ESRD }\end{array}$ & $\begin{array}{l}\text { HLA } \\
\text { mismatch }\end{array}$ & $\begin{array}{l}\mathrm{T} \\
\text { cell }\end{array}$ & $\begin{array}{l}\text { B } \\
\text { cell }\end{array}$ & $\begin{array}{l}\text { Class } \\
1\end{array}$ & $\begin{array}{l}\text { Class } \\
2\end{array}$ & & Age & Sex & $\begin{array}{l}\text { Blood } \\
\text { type }\end{array}$ & Relation \\
\hline 1 & March 18 & 51 & $M$ & $\mathrm{ORh}+$ & $\mathrm{DM}, \mathrm{HT}$ & $3 / 6$ & Neg & Neg & $20 \%$ & $20 \%$ & 157 & 45 & $F$ & $\mathrm{ORh}+$ & sister \\
\hline 2 & $\begin{array}{l}\text { August } \\
18\end{array}$ & 46 & $\mathrm{~F}$ & AB Rh+ & DM, HT & $4 / 6$ & Neg & ND & $8 \%$ & $3 \%$ & 97.3 & 48 & $\mathrm{~F}$ & B Rh+ & sister \\
\hline 3 & $\begin{array}{l}\text { August } \\
18\end{array}$ & 27 & $\mathrm{~F}$ & O Rh+ & HT, RAS & $6 / 6$ & Neg & ND & $7 \%$ & $6 \%$ & 89.2 & 54 & M & $\mathrm{ORh}+$ & uncle \\
\hline 4 & $\begin{array}{l}\text { August } \\
18\end{array}$ & 48 & M & O Rh+ & DM, HT & $0 / 6$ & Neg & ND & $29 \%$ & $19 \%$ & 108 & 41 & M & O Rh+ & brother \\
\hline 5 & March 19 & 52 & M & O Rh+ & $\mathrm{DM}, \mathrm{HT}$ & $3 / 6$ & Neg & Neg & $5 \%$ & $0 \%$ & 79.6 & 24 & M & O Rh+ & son \\
\hline 6 & March 19 & 57 & M & $\mathrm{O} R h+$ & $\mathrm{DM}, \mathrm{HT}$ & $2 / 6$ & Neg & Neg & $2 \%$ & $0 \%$ & 111 & 54 & M & O Rh+ & brother \\
\hline 7 & March 19 & 36 & M & O Rh+ & CGN & $2 / 6$ & $\mathrm{Neg}$ & Neg & $3 \%$ & $0 \%$ & 105 & 46 & $M$ & O Rh+ & brother \\
\hline
\end{tabular}

$C D C$ complement dependent cytotoxicity, PRA panel reactive antibody, KT kidney transplantation, ESRD endo-stage renal disease, $H L A$ human leukocyte antigen, $\mathrm{Cr}$ creatinine, DM diabetes mellitus, HT hypertension, Neg negative, ND not done, RAS renal artery stenosis, CGN chronic glomerulonephritis, Latest Cr were measured in July 2019 
Japanese transplant physician and nurses went to BMH before the Japanese surgeon's arrival in order to adjust everything required for transplant medicine including a final check of laboratory data and care of patient and donor. Particularly, the dose of immunosuppressants should be adjusted and administered before the operation. Japanese nurses instructed the nurses working in the operation theater before the first case how to prepare for the operation and assistance during operation. According to medical services provision in this hospital, it has succeeded to perform kidney transplant three times since the first procedure done in March 2018 in which one pair was included, the second procedure done in August 2018 involved three pairs, the third kidney transplant done in 15-16 March 2019 involved three pairs as shown in Table 6. Following the first success, we succeeded the operation three times in total involving seven pairs in the same way as that being done in the first case in a year.

\section{(ii) Summary of seven kidney transplant cases}

We summarized the data of seven cases in Table 6 . The blood type of six pairs except case 2 are all type $O$ $\mathrm{Rh}$ plus. The blood type of case 2 recipient is type $A B$ and that of donor is type A. All seven recipients were treated with $\mathrm{HD}$ at most for 1 year. Five of seven patients were ESRD due to type 2 diabetes mellitus and hypertension. Typing of human leukocyte antigen (HLA), complement-dependent cytotoxicity (CDC) test, and flow PRA (panel-reactive antibody) test were done in the examination company in South Africa. We tried to examine flow cytometry crossmatch (FCXM) at BMH, and finally, we could perform it in March 2019. Three cases who had kidney transplantation in March 2019 (cases 5 to 7 in Table 6) showed negative in FCXM T cells and B cells. Donor-specific antibody (DSA) is negative in all seven cases.

We started immunological induction therapy around 1 week before the operation. We used methylprednisolone, tacrolimus, mycophenolate mofetil, and basiliximab in the same way as in Japan. We also applied rituximab for all seven cases even though DSA was negative and blood type was compatible because we are worried on the onset of rejection. We cannot perform plasma exchange at BMH at least in May 2019. Therefore, we chose to apply rituximab to avoid rejection. The tacrolimus concentration was measured in the laboratory of $\mathrm{BMH}$, so we could adjust tacrolimus appropriately. All seven patients are well maintained regarding renal function in July 2019.

Tanzanian doctors and nurses have been able to actively perform surgery gradually as the number of kidney transplants increases.

\section{Conclusions}

Everything that we have learned should be given to people living in these countries. To get sustainability on RRT, clinical engineer should stand up and fly over the developing countries because as far as we know there is no medical engineer who is able to work in the same way in Japan.

We now surely do not ignore the treatment for the CKD patients including HD and transplant medicine. All living beings should be created equal.

We hope that African Renal Association and African Dialysis Treatment Meeting could be successfully more expanded. To teach clinical nephrology in CKD and train young doctors and co-medical staffs in their own country is essential as well as good collaboration with manufactures.

Finally, we end referring the words by Nelson Mandela "It is not where you start but how high you aim that matters for success" [1].

Can we still ignore sub-Saharan Africa?

\section{Abbreviations}

CDC: Complement-dependent cytotoxicity; DSA: Donor-specific antibody;

ESRD: End-stage renal disease; FCXM: Flow cytometry crossmatch; GDP: Gross domestic product; GNI: Gross national income; HDI: Human Development Index; HLA: Human leukocyte antigen; OECD: Organization for Economic Cooperation and Development; pmp: Per million population; PRA: Panelreactive antibody; UNDP: United Nations Development Program

\section{Acknowledgements}

We deeply thank Dr. Takao Suzuki, the president of Tokushukai Medical Group, for his continuous support for these projects. We also deeply thank Dr. Torao Tokuda, the former president of Tokushukai Medical Group, for the advocacy and opportunities to support sub-Saharan African countries. We are grateful that Dr. Milanga Mwanatambwe, Ms. Fumika Ezawa, and Mr. Kenta Ebisawa, the headquarters of Tokushukai Medical Group kept in close contact with people in various African countries and supported these projects. We thank Dr. Katsunori Miyake, the director of kidney transplant surgery in our hospital, for his surgical preparations and wonderful surgery. We are grateful that Prof. Kazunari Tanabe and Associate Prof. Masayoshi Okumi, Department of Urology, Tokyo Women's Medical University, did wonderful operations. We also thank the nephrologists, nurses, and clinical engineers of blood purification center in our hospital for supporting these projects.

Authors' contributions

SK was the leader of these projects. SH worked actively at the dialysis and transplantation sites. SK and SH were both contributors in writing the manuscript. Both authors read and approved the final manuscript.

Funding

Not applicable

Availability of data and materials

The datasets used and analyzed during the current study are available from corresponding author on reasonable request.

Ethics approval and consent to participate

Not applicable

Consent for publication

Not applicable

Competing interests

The authors declare that they have no competing interests. 
Received: 5 August 2019 Accepted: 6 November 2019

Published online: 13 January 2020

\section{References}

1. Nelson Mandela quotes. [[web page] May 20 2019]; Available from: https:// lotquotes.com/nelson-mandela-quotes/.

2. Abu-Aisha H, Elamin S. Peritoneal dialysis in Africa. Perit Dial Int. 2010;30(1): 23-8.

3. Arogundade FA, Barsoum RS. CKD prevention in Sub-Saharan Africa: a call for governmental, nongovernmental, and community support. Am J Kidney Dis. 2008;51(3):515-23.

4. World Health Organization, Atlas of African health Statistics 2018: universal health coverage and the sustainable development goals in the WHO African Region. 2018.

5. The United Nations Development programme, Human Development Indices and Indicators: 2018 Statistical Update. 2018.

6. Indicators / Data. [[web page] July 7, 2019]; Available from: https://data. worldbank.org/indicator

7. Outcome of dialysis patients aged seventy years or above - a retrospective analysis. Schweizerische medizinische Wochenschrift. 2014;144:w13920.

8. Statista. Ranking of countries with the highest prevalence of HIV in 2000 and 2017. [20 May 2019]; Available from: https://www.statista.com/statistics/2702 09/countries-with-the-highest-global-hiv-prevalence/.

9. Barsoum RS, Khalil SS, Arogundade FA. Fifty years of dialysis in Africa: challenges and progress. Am J Kidney Dis. 2015;65(3):502-12.

10. El Matri A, Elhassan EAM, Abu-Aisha $H$. Renal replacement therapy resources in Africa. Arab Journal of Nephrology and Transplantation. 2008;1(1):9-14.

11. Pozo ME, et al. An overview of renal replacement therapy and health care personnel deficiencies in sub-Saharan Africa. Transpl Int. 2012;25(6):652-7.

12. Moosa MR. The state of kidney transplantation in South Africa. South African Medical Journal. 2019;109(4):235.

13. World Health Organization, A global overview of national regulations and standards for drinking-water quality. 2018

14. Mehta RL, et al. International Society of Nephrology's Oby25 initiative for acute kidney injury (zero preventable deaths by 2025): a human rights case for nephrology. The Lancet. 2015;385(9987):2616-43.

15. Meremo AJ, et al. Acute renal failure in a Caucasian traveler with severe malaria: a case report. Clin Case Rep. 2014;2(3):82-5.

16. Meremo AJ, et al. Challenges and outcomes of haemodialysis among patients presenting with kidney diseases in Dodoma, Tanzania. BMC Nephrol. 2017;18(1):212.

17. Martin DE, et al. Strengthening global efforts to combat organ trafficking and transplant tourism: implications of the 2018 Edition of the Declaration of Istanbul. Transplant Direct. 2019:5(3):e433.

\section{Publisher's Note}

Springer Nature remains neutral with regard to jurisdictional claims in published maps and institutional affiliations.

Ready to submit your research? Choose BMC and benefit from:

- fast, convenient online submission

- thorough peer review by experienced researchers in your field

- rapid publication on acceptance

- support for research data, including large and complex data types

- gold Open Access which fosters wider collaboration and increased citations

- maximum visibility for your research: over $100 \mathrm{M}$ website views per year

At BMC, research is always in progress.

Learn more biomedcentral.com/submissions 